EDITORIAL

\title{
Normativismo e/ou Positivismo em Contabilidade: Qual o Futuro?
}

Nós, professores e profissionais mais velhos de Contabilidade, fomos educados no tradicional Normativismo Contábil. O que significou isso para nós? Que aprendemos sempre, com nossos professores e autores nacionais e estrangeiros, tendo por base a lógica dedutiva. Lógica essa calcada na definição prévia de uma Estrutura Conceitual Básica da Contabilidade, com seus Conceitos (Princípios) Fundamentais (Entidade, Regime de Competência etc.), nas características qualitativas das informações contábeis a serem observadas (Essência sobre a Forma, Oportunidade, Neutralidade etc.) e nas definições dos elementos básicos patrimoniais e suas mutações (Ativo, Passivo, Receita etc.).

Conhecemos, principalmente no início dos anos 70, algumas publicações de uma linha diferente, a Positivista, vinda do exterior, em especial dos norte-americanos, que pouco se preocupava com uma estrutura básica definida, com o considerar algo previamente como bom ou ruim, próprio ou impróprio, correto ou errado etc. Pesquisava, pura e simplesmente, o que de fato ocorria na prática; verificava se um dado procedimento contábil implicava em alguma alteração ou não no valor das ações das empresas, e daí deduzia sobre sua relevância, sem qualificá-la, conforme sua base teórico/conceitual. Mas, pensávamos: isso era simplesmente uma forma adicional de se fazer pesquisa, complementar, relativamente secundária.

Só que as coisas mudaram: por exemplo, a revista mais respeitada em pesquisa contábil no mundo, a Accounting Review, que, no início da década de 60 publicava um ou outro trabalho dessa natureza empírica, Positivista, hoje não tem lugar (faz muito tempo, aliás) para outro tipo de trabalho.

O Positivismo virou símbolo de pesquisa científica em Contabilidade; o domínio da estatística e da matemática capazes de comprovar ou não hipóteses passou a ser tão importante (às vezes mais, infelizmente) quanto o conhecimento da Contabilidade propriamente dita.

Veja-se o que ocorreu num dos mais clássicos exemplos de diferença de visão: o Princípio (ou a Convenção) do Conservadorismo, tido pelos Normativistas como necessário a adicionar credibilidade às Demonstrações Contábeis e a neutralizar um pouco o normalmente excessivo otimismo dos gestores, é visto pelos Positivistas simplesmente como uma regra criadora de assimetria: as más notícias são divulgadas rapidamente (provisões para perdas, por exemplo), mas as boas esperam por fatos corroboradores (realização da receita, por exemplo).

Hoje não há quase lugar, nas revistas de primeira linha no mundo, para trabalhos acadêmicos que não estejam fundamentados em algum nível de empirismo e calcados na lógica do Positivismo (repare que mesmo esta Revista caminha nessa direção - não há como ir contra essa força se quisermos uma publicação brasileira reconhecida internacionalmente).

Com isso, por um lado desaparecem os artigos que criam idéias, que sugerem alternativas, e crescem os que procuram as conseqüências do uso deste ou daquele procedimento (inclusive gerencial) junto aos investidores, gestores e outros usuários. Por outro lado, idéias são transformadas em papers se previamente analisadas e testadas junto a grupos estatisticamente significativos de usuários, deixando-se de perder tanto tempo infrutífero em opiniões e "achômetros". Hipóteses não são discutidas como hipóteses e sim a partir das efetivas verificações de sua validação empírica ou não. O mundo deixa de ser menos dos "donos da verdade" e mais dos que conseguem as efetivas e bem mais científicas verificações.

Só que os criativos, os inventivos e talvez até sonhadores que não tenham domínio do ferramental positivista, estão mortos! A visão dicotômica Normativismo vs. Positivismo tem a capacidade de poder matar o gérmen do que poderia ser uma fenomenal idéia por falta dessa completa lista de habilidades comprobatórias. E pode, também, destruir o entusiasmo por uma área quando se vê a comprovação da inutilidade de certos procedimentos, mas não se oferecem alternativas.

Assim, talvez chegada a hora de pensar numa convivência mais produtiva: aceitar que alguns pensam, criam, mas não são (tão) capazes de provar e comprovar. Outros, pelo contrário, são adeptos dos "laboratórios" e têm habilidade e capacidade para essas verificações empíricas, porém podem ser um tanto quanto estéreis como criadores. Quem sabe ainda tenhamos mais pesquisas e provas por parte dos Positivistas do que os usuários de fato precisam e querem (na Contabilidade Financeira - Geral - e na Gerencial), e com isso consigamos direcionar a mente e a criatividade dos pesquisadores Normativistas para produzirem essas respostas, a serem testadas pelos Positivistas, que gerarão novas demandas para os Normativistas etc. Que belo círculo virtuoso corremos o risco de ter! 